\title{
Biodiesel: Fuel for the Future (A Brief Review)
}

\author{
Owolabi R.U. ${ }^{1}$, Ade jumo A.L. ${ }^{2}$, Ade ribigbe A.F. ${ }^{3}$ \\ ${ }^{1}$ Fountain University, Industrial and Environmental Chemistry Department, Osogbo, Nigeria \\ ${ }^{2}$ Osun State University, Chemical sciences Dept., Osogbo, Nigeria \\ ${ }^{3}$ University of Science and Technology,Chemical Sciences Dept. Okiti-Pupa Ondo State,Nigeria
}

\begin{abstract}
Several attempts have been made by researchers across the globe to counter the effects of the growing information related to the finite nature of the present fossil fuel reserve and the associated hazards. Biofuel has gained global popularity in this respect as a biomass based fuel that have been tipped as a timely candidate. This review strictly focuses on biodiesel of all biomass derived biofuel.The major feedstock and their supply lines in a bid to create a balance between food and energy was considered. Various catalyst used including biocatalyst for the simple trans-esterification reaction of the feedstock (Vegetable/Used Oil; Edible/Inedible Oil and Alcohol) were analyzed. Influence of the feedstock molar ratio, temperature and time of the reaction on the conversion/yield and product purity and quality were equally reviewed. The thermo-kinetics of the biodiesel production, fuel properties of biodiesel and the trials subjected to biodiesel in terms of workability were considered for review in th is paper.
\end{abstract}

Keywords Catalyst, Biocatalyst, Trans-esterification, Molar Ratio, Thermo-kinetics, Biodiesel

\section{Introduction}

Liquid fuel is a very precious resource used abundantly and somehow indiscriminately by modern man. The primary source of liquid fuel is currently crude oil which is becoming harder and more expensive to recover as conventional reserves are depleted and as foreign suppliers increase the price for their declining reserves[1].The drastic ju mp in oil prices between 1973 and 1979 started the agitation that made many governments to adopt policies to develop alternative energy sources. With the wide majority of atmospheric scientist now agreeing that global warming is already well underway, there are now more strident calls to replace crude oil as our liquid fuel source in order to reduce the build-up of greenhouse gases in the environment[1].Thus an additional emphasis is being placed on the development, production and the use of alternative fuel considered being friendlier to the environment than fossil fuel.. In the review of[2], necessity to strictly limit the global warming was highly emphasized of which accelerated release of fossil entombed $\mathrm{CO}_{2}$ has been generally accepted as a major contributor[3].Generally, bio-sourced fuels are termed biofuel examples of which are biomethanol, bioethanol, biobutanol, biomethane, biohydrogen, biodiesel etc. This paper centers on biodiesel not only because its exhibits defined chemical and physical properties to meet the demands of engine application but because it is presently

* Corresponding author:

uthmanrash642@yahoo.com (Owolabi R.U.)

Published online at http://journal.sapub.org/ijee

Copyright (C) 2012 Scientific \& Academic Publishing. All Rights Reserved produced as a fuel on industrial scale. The functionality of biodiesel as a possible and likely candidate to replace fossil fuels as primary energy source for machineries and vehicular flow remains a driving force for scientists to keep researching into the world of biodiesel. Though, numerous popular artic les and scientific papers have cautioned against the global drive towards a biofuel economy generally, highlighting the potential impacts on food security. Since vegetable oils which are the major feed stock for biodiesel are widely grown and used for food and animal feed, hence there is the current debate "Food or Fuel?" Nonetheless, lengthy list of academia have worked on surplus and yet inedible o il as major feedstock for biodiesel. Ku mar et al.[4] discussed the importance of non-edible oil Jatropha curcus in biodiesel production. Shah et al. [5] produced biodiesel from jatropha by enzy me in a solvent free system. Attempts have also been made to produce biodiesel from non-edible sources like used frying oil, greases, tallow and lard[6-9]. Soap nut which is reported to be wildly grown in forest areas in Nepal in the elevation of 300-1900m[10] have also been presented as a suitable feedstock for biodiesel production[11]. Compared to petroleum-based diesel, the high cost of biodiesel is a major barrier to its commercialization. It costs approximately one and a half times that of petroleum-based diesel depending on feedstock oils[12-13], nevertheless, numerous literatures[14-18] revealed the importance of biodiesel especially with respect to the future energy needs.

In this review article, we examine various sources of biodiesel; edible and inedible oil, virgin oil and used oil, that is gaining increasing importance, thermo-kinetics studies and catalysis of biodiesel processing, fuel properties other process parameters, and its chances as future fuel. 


\section{History of Biodiesel}

Dr. Rudolf Diesel actually invented the diesel engine to run on a myriad of fuels including coal dust suspended in water, heavy mineral oil, and, vegetable oil. Dr. Diesel's first engine experiments were catastrophic failures. But by the time he showed his engine at the World Exhibition in Paris in 1900 , his engine was running on $100 \%$ peanut oil. Dr. Diesel was visionary. In 1911 he stated "The diesel engine can be fed with vegetable oils and would help considerably in the development of agricu lture of the countries which use it." In 1912, Diesel said, "The use of vegetable oils for engine fuels may seem insignificant today. But such oils may become in course of time as important as petroleum and the coal tar products of the present time." No doubt,this statement has come to stay.Since Dr. Diesel's untimely death in 1913, his engine has been modified to run on the polluting petroleum fuel we now know as "diesel." Nevertheless, his ideas on agriculture and $h$ is invention provided the foundation for a society fuelled with clean, renewable, locally grown fuel. Today throughout the world, countries are returning to using this form of fuel due to its renewable source and reduction in pollution[19].

3. Feedstocks for Biodiesel

The major feedstock for biodiesel is fat or oil from animal and plant respectively. Tables below show various oil used for biodiesel production.

Table 1. Production of biodiesel in Different countries

\begin{tabular}{|c|c|c|}
\hline S/N & Country & Sources of Biodiesel \\
\hline 1. & USA & $\begin{array}{c}\text { Soya Bean (Mustard is under } \\
\text { study) }\end{array}$ \\
\hline 2. & Brazil & Soya Bean \\
\hline 3. & Europe & $\begin{array}{c}\text { Rape seed oil( }>80 \text { ) and } \\
\text { Sunflower oil }\end{array}$ \\
\hline 4. & Spain & Linseed and Olive oil \\
\hline 5. & France & Sunflower oil \\
\hline 6. & Italy & Sunflower oil \\
\hline 7. & Ireland & Animal fat. Beef tallow \\
\hline 8. & Indonesia & Palm oil \\
\hline 9. & Malaysia & Palm oil \\
\hline 10. & Australia & $\begin{array}{c}\text { Animal fat, Beef tallow and } \\
\text { rapeseed }\end{array}$ \\
\hline 11. & China & Guang pi \\
\hline 12. & Germany & Rapeseed oil \\
\hline 13. & Canada & Vegetables oil/Animal fat \\
\hline 14. & India & Jatropha \\
\hline 15. & Ghana & Palm oil, Palm nut,Coconut oil \\
\hline
\end{tabular}

Source: $[20,74]$

Fatty acid composition usually obtained by gas chromatography is the major indicator of the properties of biodiesel[27]. Such composition of oil has an important role in the performance of biodiesel in diesel engines. Saturation fatty acid methyl esters increase the cloud point, cetane number, and improve stability whereas more polyunsaturation reduce the cloud point, cetane number, and stability[28-30], the details of which will be treated in the latter part of this review. The presence of free fatty acids and water in the feedstock result in the production of soap in the presence of alkali catalyst. Thus, additional steps to remove any water and either the free fatty acids or soap from the reaction mixture are required. However, the tools of biotechnology could be utilized to modify the fatty acid profile of soybean for performance enhancement, which may increase the attractiveness of biodiesel derived from this commodity crop[32]. There is still some level of disagreement in the literature over the suitability of animal fats as feedstock for biodiesel. Animal fats are solid but oil is liquid at room temperature. Thus animal fats cannot be used as fuel in its original form.In the report of Mohd Gadaffi[24],Fangrui $\mathrm{Ma}$ and Milford A. Hanna[35] submitted that animal fats contains more saturated fatty acid than vegetable oil and thus several problem will occur such as carbon deposits in the engine, engine durability and lubricating oil contamination because of incompatibility with the engine.

Table 2. Selected Restaurants in the City of Gainesville (U.S.A) to Determine Supply Lines for Waste Cooking Oil

\begin{tabular}{|c|c|c|c|}
\hline Restaurant & $\begin{array}{l}\text { Years in } \\
\text { Business }\end{array}$ & $\begin{array}{l}\text { Volume of } \\
\text { Waste Oil } \\
\text { Disposed } \\
\text { Per Month } \\
\text { In Gallons }\end{array}$ & $\begin{array}{c}\text { Amount } \\
\text { Paid For } \\
\text { Disposal } \\
\text { Per Month } \\
\text { in Dollars }\end{array}$ \\
\hline Miraku & 1 & $117 \mathrm{lbs}$ & Free \\
\hline Sandy's Place & $\begin{array}{l}1 \text { year } 2 \\
\text { months }\end{array}$ & 80 & Free \\
\hline Las Magarita & 5 & 100 & 120 \\
\hline Moraghot & 2.5 & $160 \mathrm{lbs}$ & Free \\
\hline $\begin{array}{l}\text { Boston } \\
\text { Market }\end{array}$ & 8 & 100 & 150 \\
\hline JP Gators & 20 & $50 \mathrm{lbs}$ & Free \\
\hline Napolatano & 12 & $300 \mathrm{lbs}$ & $<10$ \\
\hline $\begin{array}{c}\text { Calypso Bar } \\
\& \text { Grill }\end{array}$ & 1.5 & $72-80$ & Free \\
\hline EI Toro & 14 & $600 \mathrm{lbs}$ & 40 \\
\hline $\begin{array}{l}\text { Mildred's } \\
\text { Café }\end{array}$ & 8.5 & 30 & Free \\
\hline Chik-Fil-A & 24 & $1052 \mathrm{lbs}$ & Free \\
\hline Kotobuki & 14 & $600 \mathrm{lbs}$ & Free \\
\hline $\begin{array}{c}\text { Ballyhoo Bar } \\
\text { \&Grill }\end{array}$ & 3 & $3400 \mathrm{lbs}$ & $\begin{array}{c}511-550 \text { per } \\
\text { year. }\end{array}$ \\
\hline Porter's & 4 & 20 & 80 \\
\hline Clara's & 1 & 420 & 150 \\
\hline Hot Wok & $\begin{array}{c}10 \\
\text { months }\end{array}$ & 100 & 230 \\
\hline $\begin{array}{c}\text { Mr. Han's } \\
\text { Restaurant } \\
\text { \&Night Club }\end{array}$ & 17 & 140 & 60 \\
\hline Miya Sushi & 8 & 12 & 100 \\
\hline $\begin{array}{c}\text { Timber Creek } \\
\text { Steakhouse }\end{array}$ & 12 & 560 & 130 \\
\hline
\end{tabular}

Source:[21] 
Table 3. Fatty Acid Composition of Selected Oil

\begin{tabular}{|c|c|c|c|c|c|c|c|c|c|}
\hline $\begin{array}{c}\text { Compo } \\
\text { nent }\end{array}$ & $\begin{array}{c}\text { Jatropha } \\
{[23]} \\
\end{array}$ & $\begin{array}{c}\text { Roselle } \\
{[23]}\end{array}$ & $\begin{array}{c}\text { Coconut } \\
{[23]} \\
\end{array}$ & $\begin{array}{l}\mathrm{WCO} \\
{[22]} \\
\end{array}$ & $\begin{array}{c}\text { Pawpaw } \\
\text { [31] }\end{array}$ & $\begin{array}{l}\mathrm{P} / \mathrm{O} \\
{[26]} \\
\end{array}$ & $\begin{array}{l}\text { RSO } \\
{[25]} \\
\end{array}$ & $\begin{array}{c}\text { Canola } \\
{[26]} \\
\end{array}$ & $\begin{array}{c}\text { SoyaBean } \\
{[20]}\end{array}$ \\
\hline C8:0 & & & 3.35 & & & & & & \\
\hline $\mathrm{C} 10: 0$ & & & 3.32 & & & & & & \\
\hline $\mathrm{C} 12: 0$ & & & 32.72 & & & & & & \\
\hline $\mathrm{C} 14: 0$ & & & 18.38 & 0.41 & 0.2 & 1.0 & & 1.0 & \\
\hline $\mathrm{C} 16: 0$ & 13.77 & 18.15 & 13.13 & 8.22 & 13.9 & 42.8 & 6.1 & 5.5 & $2.3-11$ \\
\hline C16.1 & & & & 0.89 & 0.2 & & & 1.1 & \\
\hline C18:0 & 6.77 & 4.09 & 3.60 & 5.61 & 4.9 & 4.5 & 2.3 & 2.2 & $2.4-6$ \\
\hline C18:1 & 41.68 & 33.31 & 12.88 & 48.8 & 76. & 40.5 & 56.0 & 55 & $22-30.8$ \\
\hline C18:2 & 35.55 & 38.18 & 4.35 & 10.9 & 3 & 10.1 & 24.2 & 24 & $49-53$ \\
\hline $\mathrm{C} 18: 3$ & & 2.09 & & 2.68 & 0.2 & 0.2 & 6.5 & 8.8 & $2-10.5$ \\
\hline $\mathrm{C} 20: 0$ & & & & 0.56 & 4 & & 0.3 & 0.7 & \\
\hline C20:1 & & & & 0.97 & 0.3 & & 0.3 & 1,4 & \\
\hline $\mathrm{C} 22: 1$ & & & & & & & & 0.4 & \\
\hline $\mathrm{C} 22: 2$ & & & & & & & & 0.5 & \\
\hline $\mathrm{C} 24: 0$ & & & & & & & & 0.3 & \\
\hline Others & & & & 20.8 & & & & & \\
\hline $\begin{array}{c}\mathrm{MMW} \\
\mathrm{g} / \mathrm{mol}\end{array}$ & & & & & & & 889 & 882 & \\
\hline
\end{tabular}

WCO: Waste Cooking Oil, RSO: Rape Seed Oil, P/O: Palm Oil, MMW: MEAN Molecular Weight

In all, contained in the artic le of Srivathsan[61] is that the direct usage of vegetable oils as biodiesel is possible by blending it with conventional diesel fuels in a suitable ratio and these blends are stable for short term usage. The blending process is simple which involves mixing alone and hence the equipment cost is low. But direct usage of these triglyceric esters (oils) is unsatisfactory and impractical for long term usages in the available diesel engines due to high viscosity, acid contamination, and free fatty acid formation resulting in gum formation by oxidation and polymerization and carbon deposition. Hence vegetables oils are processed so as to acquire properties ( $v$ is cosity and volatility) similar to that of fossil fuels and the processed fuel can be directly used in the dieselengines. Three processing techniques are main ly used to convert vegetable oils to fuel form[62] namely, pyrolysis, micro-emulsification and trans-esterification. Pyrolysis refers to chemical change caused by application of heat to get simpler compounds from a complex compound. The process is also known as cracking. Vegetable oils can be cracked to reduce viscosity and improve cetane number. The products of cracking include alkanes, alkenes, and carboxy lic acids. Soyabean oil, cottonseed oil, rapeseed oil and other oils are successfully cracked with appropriate catalysts to get biodiesel[62]. By using this technique good flow characteristics were achieved due to reduction in viscosity. We have equally considered in this review that a lot of plant derived oil especially the inedible ones are yet to be considered as equal candiadate for biodiesel synthesis.The few ones already considered were not subjected to full pre-treatment before use.All oils contains certain percent of gum which are expected to be removed irrespective of how little they may be.Gum free oil will synthesize biodiesel of improved cloud point an pour point.

\section{Synthesis of Biodiesel}

Biodiesel are produced through a simp le technology called 
trans-esterification reaction. Degummed oil free of all forms of impurities is reacted with a reasonable alcohol (ethanol, methanol, butanol etc.)[29]. Chemically, the reaction can be represented as;

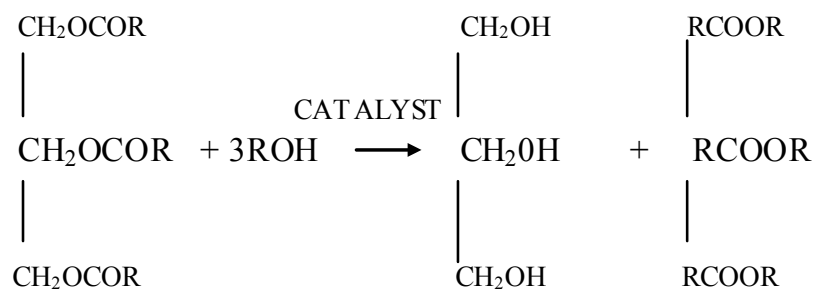

FAT/OIL ALCOHOL FATTY ACID ESTERS GLYCEROL

Several other side reaction occurs which if uncontrolled hampers conversion, product yield and quality[20]. Usually 3 parameters have effect on the trans-esterification, namely[33];

- temperature $(\mathrm{T})$, reaction

- time (t) and

- ratio of oil to alcohol.

The reaction temperature plays an important role on the quality of the products. Kapilakarn K and .Peugtong[33] reported that normally, the range of the temperature used in the process is between. $50{ }^{\circ} \mathrm{C}-65{ }^{\circ} \mathrm{C}$. The temperature which is higher than the normal boiling point of methanol $\left(68^{\circ} \mathrm{C}\right)$ causes more vaporization of methanol (loss). On the other hand, the temperature which is lower than $50{ }^{\circ} \mathrm{C}$ causes higher viscosity of biodiesel[34].The ratio of methanol to oil also affects the reaction, the higher molar ratio, the higher conversion of alcohol. The ratios, normally used, are between $5: 1$ to 10:1[35]. However using too high excess methanol can obstruct glycerin separation[36]. Divya,B and Tyagi,V.K[20] investigated the conversion rate into biodiesel using beef tallow, sunflower, and soybean feed stocks. For beef tallow, reaction rate was very slow during the first minute due to the mixing and dispersion of methanol into beef tallow, the reaction proceeded very fast for the next five minutes. An approximate yield of $80 \%$ was observed after 1 minute for soybean and sunflower oils at methanol to oil ratio of 6:1. After 1 hour, the conversions were almost the same (93\%-98\%). The effect of reaction time for palm oil at 40:1 methanol: oil with $5 \% \mathrm{H}_{2} \mathrm{SO}_{4}(\mathrm{v} / \mathrm{v})$ at $95{ }^{\circ} \mathrm{C}$ for 9 hours and obtained a maximum yield of $97 \%[42]$. However,further efforts is required to demonstrate the reactor ideal enough for biodiesel synthesis and its design and fabrication.

\section{Thermo-Kinetics of Trans-Esterification}

The feasibility of a reaction is determined from the thermodynamic parameters. Since both reactants and products are liquids, entropy change will tend to zero, hence equilibrium constant will be low[20]. Kinetics of trans-esterification reaction has at least 3 main reactions as shown in the equations stated below[37];

$$
\begin{array}{ccccc}
T G+R O H & k_{2} & \leftrightarrow & k_{1} & D G+R^{\prime} \mathrm{C}_{2} R \\
D G+R O H & k_{4} & \leftrightarrow & k_{3} & M G+R^{\prime} C 0_{2} R \\
M G+R O H & k_{6} & \leftrightarrow & k_{5} & G L+R^{\prime} C 0_{2} R
\end{array}
$$

Frequency factor, which is a measure of collisions between reactants, is always high for the forward reactions; this indicates that the reverse reaction is less favoured. Activation energy for the reverse reaction is higher than that for the forward reaction, which again should confirm the low possibility of reverse reactions. Some of the few kinetics studies that have been performed in recent times include esterification of free fatty acids in sunflower oil and ole ic acid[38-39]. Trans-esterification kinetics of soybean oil with five different catalysts have also been studied[40].Similarly, Divya and Tyagi[20] reported the study carried out by Komers et al;[41] where kinetics and mechanism of $\mathrm{KOH}$ catalyzed methanolysis of rapeseed oil for biodiesel production was investigated. The first sequence of the reaction expressed the methanolysis of rapeseed oil to biodiesel while the second sequence described the always present side reaction separation of glycerides and biodiesel by $\mathrm{KOH}$. The proposed chemical model was described by a system of differential kinetic equations which were solved numerically by two independent computing methods.Nonetheless, this aspect is yet to be fully exploited by researchers.Highly limited articles on elementary steps of the trans-esterification reaction and kinetic modeling are available in open literatures.

\section{Catalysis of Trans-esterification}

In the study carried out by Hossain and Boyce[47] inspite of higher yield, using $\mathrm{NaOH}$ as catalyst during biodiesel synthesis from waste sunflower cooking oil causes more emulsion than $\mathrm{KOH}$ and makes complicated to separate biodiesel from glycerin. For this reason, $\mathrm{KOH}$ has been screened as a catalyst whose effect in terms of concentration can be studied with respect to biodiesel production. The solution of alkaline catalyst in methanol was recommended to be prepared freshly in order to avoid the moisture absorbance and to maintain the catalytic activity[43-44]. In the article of Twar et al;[63], the essence of the titration process to get the number of gram of $\mathrm{NaOH}$ that will be used per liter of oil in the trans-esterification process was stated. This will give a rough guide on the amount of catalyst that will give an optimum yield. The experimental details goes thus; Dissolve 1 gram of $\mathrm{NaOH}$ in 1 liter of distilled water solution $(0.1 \% \mathrm{NaOH})$. Phenolphthalein solution was used to get the end point. In a smaller beaker, $1 \mathrm{ml}$ of oil was dissolved in $10 \mathrm{ml}$ of pure isopropyl alcohol. The beaker was warmed gently by standing it in some hot water, stir until all the oil dissolves in the alcohol and the mixture turns clear. 2 drops of phenolphthalein solution was added. Using a burette, $0.1 \% \mathrm{NaOH}$ solution was added drop by drop to the oil alcohol phenolphthalein solution, stirring all the time, until 
the solution stays pink for 10 seconds. The number of mls of $0.1 \% \mathrm{NaOH}$ solution used added to 5.0 will give the number of $\mathrm{NaOH}$ to be used per liter of oil[63].

Leung and Gau[26] reported that the conversion of waste cooking oil using sodium hydroxide catalysts was approximately $86 \%$. Zheng et al.[45] showed that methyl ester conversion of waste cooking oil in acid catalyzed transesterifications can reach up to $99 \%$. This process was carried out using a very high methanol to oil ratio of 250:1. In an attempt to reduce the problems with separation and soap formation associated with biodiesel production, some non-enzymatic heterogeneous catalysts have been investigated. $\mathrm{ZrO}_{2}, \mathrm{ZnO}, \mathrm{SO}_{4}{ }^{2-} / \mathrm{SnO}_{2}, \mathrm{SO}^{2-} / \mathrm{ZrO}_{2}$, zeolite, and $\mathrm{KNO}_{3} / \mathrm{ZrO}_{2}$ are some solid catalysts that were studied in the trans-esterification of palm and coconut oil[46]. The reaction was carried out at $200{ }^{\circ} \mathrm{C}, 50 \mathrm{bar}, 3 \mathrm{wt} \%$ catalysts, and a 6:1 molar ratio of methanol to oil. All the solid catalysts exhibited some activity for both palm and coconut oil. The sulfonated metal catalysts gave the highest fatty acid methyl ester yields overall. $\mathrm{ZrO}_{2}$ gave $86.3 \%$ yield for coconut oil and $90.3 \%$ yield for palm oil.

Bio-catalyzed trans-esterification as new biochemical routes to biodiesel production, are similarly gradually gaining attention as reported by Palligarnai and Michael Briggs [48] and[49-53]. Most of the articles published have used a variety of substrates such as rice bran oil, canola, sunflower oil, soybean oil, olive oil, and castor oil. Several lipases from microbial strains, including Pseudomonas fluorescens [54-55], Pseudomonas cepacia[56], Rhizo mucor miehei[55], Rhizopus oryzae[57], Candida rugosa[58], Thermo myces lanuginosus [59], and Candida antarctica[60], have been reported to have trans-esterification activity. As shown in table 4, Ojolo et al. [75], explained that the catalyst concentration increase influences the ester yield in a positive manner up to $0.80 \% \mathrm{NaOH}$ for jatropha oil after that it decreases.

What seems to be left out is the technology for the eventual separation of the lye catalyst from the glycerol.Most researchers are silent about it probably because of their wide availability and low cost.

Table 4. Yield \% of Biodiesel with Varying Amount of Catalyst

\begin{tabular}{|c|c|c|c|c|c|c|c|}
\hline $\mathrm{S}$ & Cat. & Oil & $\begin{array}{c}\text { Meth } \\
\text { anol }\end{array}$ & $\begin{array}{c}\text { RXN } \\
\text { Time }\end{array}$ & $\begin{array}{c}\text { RXN } \\
\text { Temp. }\end{array}$ & $\begin{array}{c}\text { Biodies } \\
\text { el }\end{array}$ & $\begin{array}{c}\text { Glyceri } \\
\text { ne }\end{array}$ \\
\hline $\begin{array}{c}1 \\
.\end{array}$ & $1.2 \mathrm{~g}$ & $\begin{array}{c}100 \\
\mathrm{~g}\end{array}$ & $20 \mathrm{~g}$ & $1 \mathrm{hr}$ & $65^{\circ} \mathrm{C}$ & $87.20 \%$ & $30.80 \%$ \\
\hline $\begin{array}{c}2 \\
.\end{array}$ & $1.0 \mathrm{~g}$ & $\begin{array}{c}100 \\
\mathrm{~g}\end{array}$ & $20 \mathrm{~g}$ & $1 \mathrm{hr}$ & $65^{\circ} \mathrm{C}$ & $92.40 \%$ & $27.35 \%$ \\
\hline 3 & $0.8 \mathrm{~g}$ & $\begin{array}{c}100 \\
\mathrm{~g}\end{array}$ & $20 \mathrm{~g}$ & $1 \mathrm{hr}$ & $65^{\circ} \mathrm{C}$ & $95.33 \%$ & $24.22 \%$ \\
\hline $\begin{array}{c}4 \\
.\end{array}$ & $0.6 \mathrm{~g}$ & $\begin{array}{c}100 \\
\mathrm{~g}\end{array}$ & $20 \mathrm{~g}$ & $1 \mathrm{hr}$ & $65^{\circ} \mathrm{C}$ & $74.45 \%$ & $45.37 \%$ \\
\hline
\end{tabular}

Source: [75]

S: Sample, Cat: Catalyst, RXN: Reaction

\section{Biodiesel Fuel Properties}

The fuel properties of biodiesel are discussed below;

- Specific Gravity, Density and API (America Petroleum Institute) gravity: Density is the mass of unit volume of a material at a specific temperature. A more useful unit used by the petroleum industry is specific gravity, which is the ratio of the weight of a given volume of a material to the weight of the same volume of water measured at the same temperature. Specific gravity is used to calculate the mass of oils. The API (American Petroleum Institute) gravity is another way to express the relative masses of oils. The API gravity could be calculated mathematically using the equation:

$$
{ }^{\circ} A P I=\frac{141.5}{S p . G r \frac{60}{{ }^{\circ} 60 F}}-131.5
$$

A low API gravity indicates heavier oil, while a higher API gravity means a lighter crude or product. Specific gravities of crude oils roughly range from 0.82 for lighter Crudes to over 1.0 for heavier oil.

- Flash Point: This is the minimum temperature at which the vapour from oil sample will give a momentary flash on application of a standard flame under specific test conditions. This is used to predict the possible fire hazard during transportation, storage and handling.

- Pour Point, Cloud Point: The pour point of a crude oil or product is the lowest temperature at which oil is observed to flow under the conditions of the test. Handling and transporting oils and heavy fuels is difficult at temperatures below their pour points .Often, chemical additives known as pour point depressants are used to improve the flow properties of the fuel. The temperature at which wax crystals begin to form on the surface of the biodiesel is the cloud point.

- Aniline Point, Diesel Index: Aniline Point is the minimum temperature at which equal volu mes of anhydrous aniline and oil mix together. A low aniline point indicates low diesel index. Diesel index is a measure of ignition quality of a fuel. Aniline point can also predict the amount of carbon present in the oil as given by the equation

$$
\text { \% } C=1039.4 n_{D}^{20}-470.4 d_{20}-0.567 A P\left({ }^{\circ} \mathrm{C}\right)-1104.42
$$

Where $n_{D}^{20}=$ Refractive index at $20{ }^{\circ} \mathrm{C}$ and $d_{20}=$ Density at $20{ }^{\circ} \mathrm{C}$.

- Viscosity: This is the resistance to flow of oil. Ease of starting depends on viscosity. Glycerin contamination may cause biodiesel viscosity to increase[20].Production of biodiesel with much reduced viscosity and cloud point can be found in the patent of Nourreddini[68]. Tables 4-5 shows the fuel properties of biodiesel from various sources. 
Table 5. Fuel Properties of Biodiesel from various sources

\begin{tabular}{|c|c|c|c|c|c|c|c|c|c|}
\hline $\begin{array}{c}\text { Fuel } \\
\text { Propert } \\
\text { y }\end{array}$ & $\begin{array}{c}{ }^{1} \text { (Petroleu } \\
\mathrm{m} \\
\text { diesel) }\end{array}$ & $\begin{array}{c}{ }^{2}(\mathrm{PKO} \\
\text { Biodies } \\
\text { el } \\
\end{array}$ & $\begin{array}{c}3 \\
\text { Rapeseed } \\
\text { Biodiesel }\end{array}$ & $\begin{array}{l}{ }^{4} \text { Canola } \\
\text { Biodiesel }\end{array}$ & $\begin{array}{c}5 \\
\text { Jathropha } \\
\text { Biodiesel }\end{array}$ & $\begin{array}{c}6 \\
\text { Soyabean } \\
\text { Biodiesel } \\
\end{array}$ & $\begin{array}{l}{ }^{7} \mathrm{WCO} \\
\text { Biodiesel }\end{array}$ & $\begin{array}{c}{ }^{8} \text { Biodiese } \\
1 \\
\text { Standard }\end{array}$ & $\begin{array}{c}{ }^{9} \text { MilkB } \\
\text { ush }\end{array}$ \\
\hline $\begin{array}{l}\text { Specific } \\
\text { Gravity }\end{array}$ & 0.853 & 0.883 & 0.876 & 0.878 & 0.880 & 0.885 & 0.858 & $0.875-0.9$ & 0.885 \\
\hline $\begin{array}{c}\text { Flash } \\
\text { Point }{ }^{0} \mathrm{C}\end{array}$ & 74 & 167 & 124 & 177 & 170 & 178 & & 100 & 160 \\
\hline $\begin{array}{c}\text { Pour } \\
\text { Point }{ }^{0} \mathrm{C}\end{array}$ & -16 & 2 & -2 & -1 & & & 7 & & \\
\hline $\begin{array}{c}\text { Cloud } \\
\text { Point }{ }^{0} \mathrm{C}\end{array}$ & -12 & 6 & -10 & -6 & & 1 & 10 & & \\
\hline $\begin{array}{l}\text { Aniline } \\
\text { Point }{ }^{0} \mathrm{C}\end{array}$ & & & & & & & 4 & & \\
\hline $\begin{array}{c}\text { API } \\
\text { Gravity }\end{array}$ & & & & & & & 33.42 & & \\
\hline $\begin{array}{c}\text { Heat of } \\
\text { Combus } \\
\text { tion } \\
\mathrm{Cal} / \mathrm{g}\end{array}$ & & & & & & & 10854.06 & & \\
\hline $\begin{array}{c}\text { Viscosit } \\
\mathrm{y} @ \\
40^{\circ} \mathrm{C} \\
\mathrm{mm}^{2} / \mathrm{s}\end{array}$ & 2.847 & 4.839 & 6.170 & 4.892 & $5.65 \mathrm{cSt}$ & 4.5 & 1.89 & 5.00 & $\begin{array}{l}4.82 \\
\text { (cst) }\end{array}$ \\
\hline $\begin{array}{l}\text { Cetane } \\
\text { Index }\end{array}$ & & & & & 50 & 45 & 10.96 & 49 & 57 \\
\hline $\begin{array}{l}\text { Diesel } \\
\text { Index }\end{array}$ & & & & & & & 1.337 & & \\
\hline $\mathrm{PH}$ & & & & & & & 7.43 & & \\
\hline
\end{tabular}

${ }^{14}[64] ;{ }^{5} 65$ and 66]; ${ }^{7}[21] ;{ }^{8}$ DIN V51606 (Germany) $[67] ;{ }^{9}[73]$

Table 6. Heat of a Combustion and Specific gravity of other vegetable biodiesel fuel

\begin{tabular}{ccc}
\hline Fuel Type & $\begin{array}{c}\text { Heat of } \\
\text { Combustion kj/kg }\end{array}$ & $\begin{array}{c}\text { Specific } \\
\text { Gravity }\end{array}$ \\
Diesel Fuel & 43350 & 0.815 \\
Sun Flower Biodiesel & 40579 & 0.878 \\
Cotton Seed Biodiesel & 40580 & 0.874 \\
Soya Bean Biodiesel & 39760 & 0.872 \\
Rape Seed Biodiesel & 37620 & 0.914 \\
Pawpaw Seed biodiesel & 45342 & 0.867 \\
WCO & 45479 & 0.858
\end{tabular}

Source:[21].

\section{The Energy Balance of Biodiesel}

The net energy balance of various ethanol and biodiesel feedstock has been a center of debate within scientific and policy circles. The energy balance denotes to "a comparison of the energy stored in a fuel to the energy required to grow, process and distribute that fuel"'69]. According to most of the sources, biodiesel provides a positive energy balance: for every unit of energy needed to produce biodiesel, 2.5 to 3.2 units of energy are gained. Evidence suggests that virgin oil from sources other than Soya may have even higher energy content. Overall, biodiesel is said to have the highest energy yield than any liquid fuel[70].

\section{Field Trials of Biodiesel}

In recent years, trials on automobiles using biodiesel have been conducted by several institutions in India which have confirmed that biodiesel can reduce wear and tear of engines and reduce oil pollution significantly[71]. At the University of Ilorin , Kwara State, Nigeria, biodesel obtained from jatropha seed oil was used to test run a fossil diesel generator for hours [72].

\section{Conclusions and Future Prospects}

Energy is an essential factor in industrial growth and in provision of required services that improve the quality of life of mankind. Biodiesel, of the family of biofuel, has been described in this review as a fuel with necessary potentials to replace fossil diesel in future. The trials biodiesel and its blend have undergone is a confirmatory test to all advantages including environmental benefits accrued to it thereby plays a vital role in meeting future fuel requirements. The availability of major feedstock namely oil from bio-sources and simplicity of the trans-esterifcation technology that ensures its conversion to biodiesel are added advantage in terms of the future needs of biodiesel. The use of inedible oil and waste frying/cooking oil has equally assisted in establishing a balance between energy and food security.However, serious efforts have to be intensified on design of large scale bio-refineries for future biodiesel production. 


\section{REFERENCES}

[1] Lim,L.H.,Macdonald,D.G and Hill,G.A.,Immobilized Barley $\alpha$-Amylase for Hydrolysis of Starch Particles.Final report for Saskatchenan Agriculture Development and Food under contract 20000155,(2001)

[2] Stern, N;The Economics Of Climate Change. The Stern Review. Cabinet Office-HMTreasury.Cambridgeuniversitypr esshttp://Www.Hm- Treasury.Gov.Uk/Independent_Reviews /Stern_Review_Economics_Climate_Change/Stern_Review _Report.Cfm (2006)

[3] Houghton,J.T, DingY, Griggs,D.J, Noguer M,Van Der Linden,P.J., Xiaosu D(Eds)(2001)Climate Change :The Scientific Basis.Contributionof Working Group I To The Third Assessment Report of The Intergovernmental Panel on Climate Chan ge(IPCC).Canbridge University Press,UK,944, (2001).

[4] Kumarn.,Sharma,P.B., "Jatropha Curcus - A Sustainable Source for Production Of Biodiesel", Journal Of Scientific And Industrial Research, Vol. 64(11), Pp. 883-889,(2005).

[5] Shah,S Gupta,M.N, "Lipase Catalyzed Preparation of Biodiesel From Jatropha Oil in a Solvent Free System", Process Biochemistry, Vol. 42(3), Pp.409-414,(2007).

[6] Mittelbach M, Pokits B And Silberholz A Production and Fuel Properties of Fatty Acid Methyl Esters from Used Fry ing Oil. Liquid Fuels From Renewable Sources: Proc. of An Alternative Energy Conf., St. Joseph. Mich. ASAE. Pp: 74-78,(1992).

[7] Alcantara R, Amores J, Canoira L, Hidalgo E, Franco MJ, Navarro A Catalytic Production of Biodiesel From Soybean Oil, Used Frying Oil and Tallow. Biomass Bioenerg. 18, 515 $-527,(2000)$.

[8] Canakci M and Gerpen J.V Biodiesel Production from Oils and Fats with High Free Fatty Acids. Trans. ASAE. 44, 1429-1436,(2001).

[9] Dorado M.P, Ballasteros E, Almeida J.A, Schellert C, Lohrlein H.P And Krause R (2002) An Alkali Catalyzed Transesterification Process For High Free Fatty Acid Waste Oils. Trans. ASAE. 45,525- 529,(2002).

[10] Olsen, C.S. A Qualitative Assessment of The Sustainability of Commercial Non-Timber Forest Product Collection in Nepal. Forestry Discussion Paper 12, Royal Veterinary and Agricultural University, Copenhagen, Pp. 30,(1997).

[11] Arjun B. C, Martin S. T, Suzanne M. B, Chris W.K and Rafiqul I.M , Non-Edible Plant Oils as New Sources for Biodiesel Production, Int. J. Mol. Sci. 9, 169-180,(2008).

[12] Prokop, T., Personal Communication, Imperial Western Products, 14970 Chandler St., Coachella, CA 91720,(2002).

[13] Lott, M., (2002). Personal Communication, QSS Group Inc., 4500 Forbes Boulevard, Suite 200, Lanham, MD 20706,(2002).

[14] Demirbas, M., Balat, M., Recent Advances on the Production and Utilization Trends of Bio-Fuels: A Global Perspective. Energy Conversion and Management 47, 2371-2381,(2006).

[15] Marchetti, J., and Errazu, A., Techno-economic Study of Supercritical Biodiesel Production Plant. Energy Conversion and Management 49, 2160-2164 (2008).
[16] Mohibbe Azam, M., Waris, A., Nahar, N., Prospects and Potential of Fatty Acid Methyl Esters of Some Non-Traditional Seed Oils for use as Biodiesel in India.Biomass and Bioenergy 29, 293-302,(2005).

[17] Sarin, R., Sharma, M., Sinharay, S., Malhotra, R., Jatropha-Palm Biodiesel Blends: An Optimum Mix For Asia. Fuel 86, 1365-1371,(2007).

[18] Zhang, Y., Dubé, M., Mclean, D., Kates, M., Biodiesel Production from Waste Cooking Oil: 2. Economic Assessment And Sensitivity Analysis. Bioresource Technology 90, 229-240,(2003) .

[19] www.Biofuels.Coop

[20] Divya,B;and Tyagi,V.K,(2006),Biodiesel:Source,Production, Composition,Properties and Its Benefits.J.Oleo Sci., Vol.55,No.10,487-502,(2006).

[21] Owolabi R U, Osiy emi N A, Amosa M K And Ojewumi M E, Biodiesel from Household/Restaurant Waste Cooking Oil (WCO), J Chem Eng Process Technology, 2:4,(2011).

[22] Issariyakul, T.; Kulkarni, M.G.; Dalai, A.K.; Bakhshi, N.N. Production of Biodiesel Form Waste Fryer Grease Using Mixed Methanol/Ethanol System. Fuel Processing Technology , 88, 429- 436,(2007).

[23] Piy anuch, N And Sasiwimol, W; Biodiesel Production From Mixtures of Vegetable Oil and Used Cooking Oil, International Conference on the Role of Universities in Hands-On Education ,Rajaman gala University of Technology Lanna, Chiang-Mai, Thailand,(2009).

[24] Mohd Ghadafi,I, Biodiesel Production from Waste Cooking Oil Via Single Steps Tranesterification Process with the aid of Sodium Methoxide as a Catalyst,B.Sc Project,Faculty Of Chemical \& Natural Resources Engineering Universiti Malaysia Pahang (2008).

[25] Rice,B ,Frohlich,A,Leonard,R (1997), Bio-Diesel Production Based on Waste Cooking Oil: Promotion of The Establishment of an Industry in Ireland,Altener Contract No. Xvii/4.1030/A1/77/95/Irl,(1997).

[26] Leung, D.Y.C.; Guo, Y. , Transesterification of Neat and Used Fry ing Oil: Optimization for Biodiesel Production. Fuel Processing Technology 87, 883-890,(2006).

[27] Kumar M.S., Ramesh, A., Nagalingam, B., An Experimental Comparison of Methods to use Methanol and Jatropha Oil in a Compression Ignition Engine, Biomass and Bioenergy, 25, 309-318,(2003).

[28] Dorado, M.P., Ballesteros, E., López, F.J. And Mittelbach, M., Optimization of Alkali-Catalyzed Transesterification of Brassica Carinata Oil for Biodiesel Production, Energy \& Fuels, 18,7-83,(2004).

[29] Arjun, B. C., Chris W.K And Rafiqul I.M ,Waste Cooking Oil as an Alternative Feedstock for Biodiesel Production, Energies , 1, 3-18,(2008).

[30] Kinney A.J, Clemente T.E Modifying Soybean Oil For Enhanced Performance In Biodiesel Blends. Fuel Process Technol 86(10):1137-1147,(2005)

[31] Ghazali,H.M; Puangsri,T; Abdulkarim,S.M;(2004). Properties of Carica Papaya.(Papaya) Seed Oil Following Extractions using Solvent and Aqueous Enzymatic Methods, 
Journal Of Food Lipids, 12, 62-76,(2004).

[32] Gerpen, J.V. "Biodiesel Processing and Production", Fuel Processing Technology 86 1097-1107, (2005).

[33] Kapilakarn K And .Peugtong. A., A Comparison of Costs of Biodiesel Production From Transesterication International Energy Journal 8 , 1-6,(2007).

[34] Darnoko, D. And M. Cheryan., Kinetic of Palm Oil Transesterification in a Batch Reactor. JAOCS 77(12):1263-1267,(2000).

[35] Fangrui Ma And Hanna, M. A. Biodiesel Production: A Review, Bioresource Technology 70:1-15,(1999).

[36] Tongurai, C.; Klinpikul, S.; Bunyakan, C. And Kiatsimkul, P. Biodiesel Production From Palm Oil, Songklanakarin J. Sci. Technol, 23(Suppl.): Oil Palm:831-841,(2002).

[37] Noureddini, H.and D. Zhu. Kinetic of Transesterification of Soybean Oil, JAOCS 74 (11): 1457-1463,(1997).

[38] Berrios M, Siles J, Martin M.A and Martin A .A Kinetic Study of the Esterification of Free Fatty Acids (FFA) in Sunflower Oil. Fuel. 86, 2383-2388,(2007).

[39] Kraai G.N, Winkelman J.G.M, De Vries J.G And Heeres H.J. Kinetic Studies on the Rhizomucor Miehei Lipase Catalyzed Esterification Reaction of Oleic Acid with 1-Butanol in Biphasic System. Biochem Engg. J. 41, 87-94,(2008).

[40] Singh A.K and Fernando S.D. Reaction Kinetics of Soybean Oil Transesterification using Heterogenous Metal Oxide Catalysts. Chem. Eng. Technol. 30, 1716-1720,(2007).

[41] Komers,K.,Skopal,F.,Stloukal,R.,Machek, Kinetics and Mechanism of the KOH Catalyzed Methanoly sis of Rapeseed Oil for Biodiesel Production,Journal of Lipid Science and Technology,Vol.104,728-737,(2000).

[42] Kamini,N.R., and Lefugi,H., Lipase Catalysed Methanolysis of Vegetable Oil in Aqueous Medium by Cryptococus Spp.S-2,Process Biotecnol.,Vol.37,405,(2001).

[43] Meher, L.C., Sagar, D.V., Naik, S.N., Technical aspects of Biodiesel Production by Transesterification-A Review, Renewable and Sustainable Energy Reviews, 10(3),248-268 (2006a)

[44] Meher, L.C., Sagar, D.V., Naik, S.N., Optimization of Alkali-Catalyzed Transesterification of Pongamia Pinnata Oil for Production of Biodiesel, Bioresource Technology, 97,1392-1397,(2006b).

[45] Zheng, S.; Kates, M.; Dube, M.A.; Mclean, D.D. Acid-Catalyzed Production of Biodiesel from Waste Frying Oil. Biomass And Bioenergy,30, 267-272,(2006).

[46] Jitputti J, Kitiyanan B, Rangsunvigit P, Bunyakiat K, Attanatho L, Jenvanitpanjakul P Transesterification of Crude Palm Kernel Oil and Crude Coconut by different Solid Catalysts. Chem Eng J 116:61-66,(2006).

[47] Hossain,A.B.M.S., and Boyce,A.N., Biodiesel Production from Waste Sunflower Cooking Oil as an Environmental Recycling Process and Renewable En ergy, Bulgarian Journal Of Agricultural Science, 15 (No 4), 312-317,Agricultural Academy,(2009).

[48] Palligarnai T. V and Michael Briggs, Biodiesel Production-Current State of the Art and Challenges, J Ind
Microbiol Biotechnol.(2008).

[49] Chang, H.M, Liao, H.F, Lee, C.C, Shieh, C.J Optimized Synthesis of Lipase-Catalyzed Biodiesel by Novozym 435. J Chem Technol Biotechnol 80(3):307-312,(2005).

[50] De Oliveira D, Di Luccio M, Faccio C, Dalla Rosa C, Bender J.P,Lipke N, Menoncin S, Amroginski C, De Oliveira J.V, Optimization of Enzymatic Production of Biodiesel from Castor Oil in Organic Solvent Medium. Appl Biochem Biotechnol 113-116:771-780,(2004).

[51] Fukuda H, Kondo A, Noda H, Biodiesel Fuel Production By Transesterification of Oils. J Biosci Bioeng 92(5):405-416,(2001).

[52] Lai C.C, Zullaikah S, Vali S.R, Ju Y.H , Lipase-Catalyzed Production Of Biodiesel From Rice Bran Oil. J Chem Technol Biotechnol 80(3):331-337,(2005).

[53] Noureddini H, Gao X, Philkana RS ,Immobilized Pseudomonas Cepacia Lipase For Biodiesel Fuel Production From Soybean Oil. Bioresour Technol 96(7):769-777,(2005).

[54] Iso M, Chen B.X, Eguchi M, Kudo T, Shrestha S ,Production of Biodiesel Fuel from Triglycerides and Alcohol using Immobilized Lipase. J Mol Catal B Enzym 16(1):53-58,(2001)

[55] Soumanou M.M and Bornscheuer U.T, Improvement in Lipase Catalyzed Synthesis of Fatty Acid Methyl Esters From Sunflower Oil. Enzyme Microb Technol 33(1):97-103,(2003 ) .

[56] Deng L, Xu X.B, Haraldsson G.G, Tan T.W, Wang F Enzymatic Production Of Alkyl Esters Through Alcoholysis: A Critical Evaluation Of Lipases And Alcohols. J Am Chem Soc 82(5):341-347,(2005).

[57] Matsumoto T, Takahashi S, Kaieda M, Ueda M, Tanaka A, Fukuda H, Kondo A Yeast Whole-Cell Biocatalysts Constructed by Intracellular Overproduction of Rhizopus Oryzae Lipase is Applicable to Biodiesel Fuel Production. App1Microbiol Biotechnol 57(4):515-520,(2001).

[58] Chen J.W, Wu W.T Regeneration of Immobilized Candida Antarctica Lipase for Transesterification. J Biosci Bioeng 92(2):231-237(2003)

[59] Xu Y.Y, Du W, Zeng J, Liu D.H ,Conversion of Soybean Oil to Biodiesel Fuel using Lipozyme TL $1 \mathrm{M}$ in a Solvent-Free Medium. Biocatal Biotransformation 22(1):45-48(2004).

[60] Lai C.C, Zullaikah S, Vali S.R, Ju Y.H . Lipase-Catalyzed Production of Biodiesel from Rice Bran Oil. J Chem Technol Biotechnol 80(3):331-33,7(2005).

[61] Srivathsan,V.R, Srinivasan,L.N,Karuppan,M, An Overview Of Enzymatic Production Of Biodiesel, Bioresour. Technol. (2007), Doi:10.1016/J.Biortech.2007.04.060,(2007)

[62] Ma, F., Hanna, M.A., Biodiesel Production: A Review. Bioresour. Technol. 70, 1-15,(1999).

[63] Tiwari, A.K., Kumar, A., Raheman, H; Biodiesel Production from Jatropha Oil Jatropha Carcus) with High Free Fatty Acids: An Optimized Process. Biomass and Bioenergy, Pp569 - 575,(2008).

[64] Alamu, O.J; Akintola,T.A; Enweremadu C.C And Adeleke .A.E(2008) Characterization of Palm-Kernel Oil Biodiesel Produced through NaoH-Catalysed 
Transesterification Process, Scientific Research and Essay Vol.3 (7), Pp. 308-311,(2008).

[65] Reddy, J.N and Ramesh, A. Parametric Studies for Improving the Performance of a Jatropha Oil fuelled Compression Ignition Engine. Ren ewable Energy, 31, 1994-2016,(2005).

[66] Sandip K .H and Ahindra Nag,.Utilization of Three Non-Edible Vegetable Oils for the Production of Biodiesel Catalysed by Enzyme, The Open Chemical Engineering Journal, 2, 79-83,(2008).

[67] Biodiesel Report;Natonal Biodiesel Board,Jefferson City, MO.(1996).

[68] Noureddini,H. US patent.174 501,(1997).

[69] Tickell, J., From the fryer to the Fuel Tank:The Complete guide to using Vegetable Oil as an alternative Fuel. 3rd edition, Tickell Energy Consulting, Tallahassee, Florida. P. 36, 5254,(2000).

[70] Anjan, B.K P., Rachna, C, Azeez P.A Biodiesel: Freedom from Dependence on Fossil Fuels. Nature Precedings : doi:10.1038/npre.2008.2658.1,(200)

[71] Sudarsan KG and Anupa m a P M (2006). The relevance of biofuels. Current Science. 90 (6): 748749,(2006).

[72] Belewu,,Challenges of Biofuel Production in Nigeria. Semina $r$ presented at Fountain university, Osogbo,Nigeria,(2011).

[73] Olatunji,O.M , Akor, A.J , Abowei, J.F.N and Akintayo, C.O. Transesterification for the preparation of Biodiesel from Crude Oil of Milk Bush, Research Journal of Environmental and Earth Sciences 3(4): 358-363 , (2011)

[74] Duku, M. H., Status of Biofuels Development in Ghana. ICS-UNIDO-MPOB, Workshop on Biofuels from Palm Oil: Emerging Technologies and their Assessments, Kuala Lumpur, Malaysia, (2007)

[75] Ojolo,S.J , Ogunsina, B.S , Adelaja, A.O Ogbonnaya ,M , Study of an Effective Technique for the Production of Biodiesel from Jatropha Oil, Journal of Emerging Trends in Engineering and Applied Sciences (JETEAS) 2 (1): 79-86,(2011) 